\title{
KONSUMSI OKSIGEN BENIH IKAN KERAPU BEBEK (Cromileptes altivelis) UKURAN PANJANG 5-7 CM
}

\author{
Oxygen Consumption Level of Humpback Grouper Juvenile (Cromileptes altivelis) \\ with Lenght Size of 5-7 cm
}

Oleh:

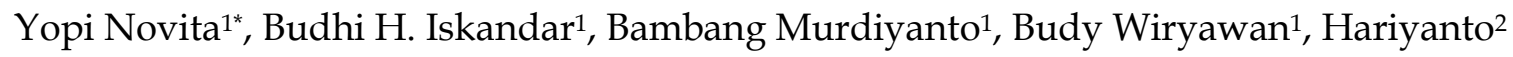

\author{
${ }^{1}$ Departemen Pemanfaatan Sumber Daya Perikanan, FPIK, IPB \\ 2 Badan Pengkajian dan Penerapan Teknologi. \\ "Korespondensi: yop_novita@yahoo.com
}

Diterima: 5 Mei 2010; Disetujui: 21 Januari 2011

\begin{abstract}
Disolved oxygen plays an important role for fish living in its life environment. Information on the ammount of oxygen consumption of a fish in certain volume of water is needed in order to give balancing between the ammount of disolved oxygen and fish in it. The objective of this research is obtaining oxygen consumption level of a juvenile of humpback grouper (Cromileptes altivelis) of 5-7 $\mathrm{cm}$ body length. Oxygen consumption of fish was measured using a tube that equiped with DO tool (dissolved oxygent, DO), and the tube was filled by sea water. Measurement of oxygen consumption of juvenil was done by measuring the concentration of dissolved oxygen from sea water in the respirometer tube, began when fish had entered into the respirometer tube up to two hours observation. The result showed that oxygen consumption rate of a juvenile of humpback grouper (Cromileptes altivelis) of 5-7 cm length, is ranging between 0.816 and $1.734 \mathrm{mg} / \mathrm{hour}$.
\end{abstract}

Key words: humpback grouper, juvenile fish, oxygen consumption

\begin{abstract}
ABSTRAK
Kelangsungan hidup ikan sangat ditentukan oleh ketersediaan oksigen terlarut di lingkungan ikan. Informasi seberapa besar konsumsi oksigen ikan sangatlah diperlukan agar jumlah ikan dalam suatu volume air seimbang dengan ketersediaan oksigen terlarutnya. Tujuan penelitian ini adalah mendapatkan nilai konsumsi oksigen dari benih ikan kerapu bebek (Cromileptes altivelis) berukuran panjang total $5-7 \mathrm{~cm}$. Pengukuran konsumsi oksigen ikan dilakukan dengan menggunakan tabung yang yang dilengkapi dengan alat pengukur DO (dissolved oxygent, DO) dan ke dalam tabung telah diisi air laut hingga penuh. Pengukuran konsumsi oksigen dari benih ikan dilakukan dengan mengukur nilai konsentrasi oksigen terlarut dari air laut di dalam tabung respirometer, mulai dari awal saat ikan baru dimasukkan ke dalam tabung respirometer hingga dua jam pengamatan. Berdasarkan hasil penelitian diperoleh nilai konsumsi oksigen satu ekor benih ikan kerapu bebek (Cromileptes altivelis) ukuran panjang 5-7 cm adalah antara 0,816-1,734 mg/jam.
\end{abstract}

Kata kunci: ikan kerapu bebek, benih ikan, konsumsi oksigen

\section{PENDAHULUAN}

\section{Latar Belakang}

Kerapu bebek (Cromileptes altivelis) merupakan salah satu komoditi perikanan yang memiliki nilai ekonomis yang tinggi, terlebih jika dalam kondisi hidup. Saat ini ketersediaan kerapu bebek sebagian besar dipenuhi dari hasil budidaya, disebabkan ukuran ikan kerapu yang dihasilkan lebih seragam dan dapat disediakan dalam jumlah banyak. Keberhasilan usaha budidaya pembesaran ikan kerapu bebek sangat 
tergantung kepada ketersediaan benih yang berkualitas dalam jumlah yang banyak. Benih ikan yang berkualitas dipengaruhi oleh cara pemeliharaan benih dan transportasi dari tempat pembenihan ke tempat pembesaran ikan. Salah satu faktor keberhasilan sistem pemeliharaan dan transportasi ikan adalah kepadatan ikan (densitas ikan, ekor/liter) di dalam suatu media. Tinggi rendahnya densitas ikan di dalam suatu media tergantung kepada ketersediaan oksigen terlarut di dalam sistem tersebut yang sesuai dengan kebutuhan konsumsi oksigen dari ikan.

Informasi tentang nilai konsumsi oksigen dari benih ikan kerapu bebek ukuran panjang total antara $5-7 \mathrm{~cm}$ belum diketahui hingga saat ini. Nilai konsumsi oksigen ikan diketahui dari respirasi yang dilakukannya. Schreck and Moyle (1990) mengemukakan bahwa respirasi pada ikan termasuk proses mengambil oksigen dari lingkungan dan mengeluarkan gas buang ke lingkungan. Tingkat konsumsi oksigen ikan diukur menggunakan respirometer. Beberapa penelitian telah dilakukan untuk mengukur tingkat konsumsi oksigen ikan dengan menggunakan respirometer (Zimmermann and Kunzmann (2001), Grøttum and Sigholt (1998) dan Fivelstad and Smith (1991), Berg et al. (1993), Kazakor and Khalyapina (1981) dalam Grøttum and Sigholt (1998)).

FishVet.Inc. (2000) menyatakan bahwa ikan yang berada tidak dalam lingkungan yang biasa ditempatinya akan mengalami stres. Grøttum and Sigholt (1998) menyebutkan bahwa metabolisme ikan dalam tabung respirometer lebih tinggi dibandingkan dengan di kolam budidaya, meskipun ikan tersebut saat pengukuran konsumsi oksigen telah dipuasakan dan diaklimatisasikan terlebih dahulu untuk menurunkan metabolisme. Oleh karena itu, dalam penelitian ini akan dikaji konsumsi oksigen individu dan kelompok benih ikan kerapu bebek. Hal ini perlu dilakukan untuk mendapatkan nilai konsumsi oksigen benih ikan kerapu yang lebih dekat dengan kondisi yang sesungguhnya, yaitu ikan dalam kondisi stres yang seminimal mungkin.

\section{Tujuan Penelitian}

Tujuan penelitian ini adalah menentukan konsumsi oksigen yang dibutuhkan benih ikan kerapu bebek (Chromileptes altivelis) ukuran panjang total antara 5-7 $\mathrm{cm}$ secara individu dan kelompok.

\section{METODE PENELITIAN}

Penelitian ini dilakukan selama satu bulan, yaitu pada bulan Desember 2009 di Labo- ratorium Desain dan Dinamika Kapal, Bagian Kapal dan Transportasi Perikanan, Departemen PSP FPIK IPB. Pengukuran konsumsi oksigen benih ikan menggunakan respirometer dengan mengukur konsentrasi oksigen terlarut dalam tabung respirometer. Perlakuan yang diterapkan adalah: pengukuran konsumsi oksigen benih ikan secara individu (individu $i k a n=l_{i}$ ) dan kelompok (Ikan kelompok $=l_{k}$ ). Pengukuran konsumsi oksigen benih ikan kelompok dilakukan dengan mengukur tiga ekor benih ikan kerapu dalam satu tabung respirometer. Penggunaan tiga ekor benih ikan saat pengukuran konsumsi oksigen ikan kelompok ( $\mathrm{k}_{\mathrm{k}}$ ) adalah mengacu pada kepadatan benih ikan kerapu saat dilakukan aklimatisasi di akuarium penampungan sebelum eksperimen dilakukan yaitu sebesar 1,67 ekor/liter. Selain pengukuran pada saat ada ikan di dalam tabung respirometer, pengukuran konsentrasi oksigen terlarut juga dilakukan pada saat tidak ada ikan di dalam tabung respirometer (kondisi kosong). Pengukuran ini dimaksudkan sebagai koreksi terhadap pengurangan konsentrasi oksigen terlarut yang diakibatkan oleh respirasi mikroorganisme yang mungkin saja terdapat di dalam tabung respirometer tersebut.

Pengukuran konsumsi oksigen ikan pada perlakuan $\mathrm{l}_{\mathrm{i}}$ dan $\mathrm{l}_{\mathrm{k}}$ dilakukan masing-masing sebanyak 3 kali. Lamanya waktu setiap pengukuran konsumsi oksigen benih ikan adalah 2 jam.

\section{Alat dan Bahan}

Alat yang digunakan terdiri atas:

1) 1 unit respirometer (closed system) (Gambar 1), yang terdiri dari:

- 2 buah tabung kaca, masing-masing tabung diisi dengan air laut hingga penuh (2,04 liter).

- DO meter, merk Lutron: tipe YK-2001PH (1 unit)

- Waterpump dengan kekuatan: 400 liter/jam (water flow) (1 unit)

- Aerator (1 unit)

- Selang dengan diameter $5 \mathrm{~mm}$

2) 1 unit video recorder Bahan yang digunakan terdiri dari air laut dan ikan kerapu bebek dengan ukuran panjang antara $5-7 \mathrm{~cm}$.

3) Nilai oksigen terlarut (DO) dalam air ( $\mathrm{mg}$ $\mathrm{O}_{2} /$ liter) saat awal dan akhir pengukuran

4) Kandungan amoniak $\left(\mathrm{NH}_{3}\right)$ (mg/liter) dalam air saat awal dan akhir pengukuran

5) Suhu air laut dalam respirometer $\left({ }^{\circ} \mathrm{C}\right)$

6) Suhu ruang $\left({ }^{\circ} \mathrm{C}\right)$ 


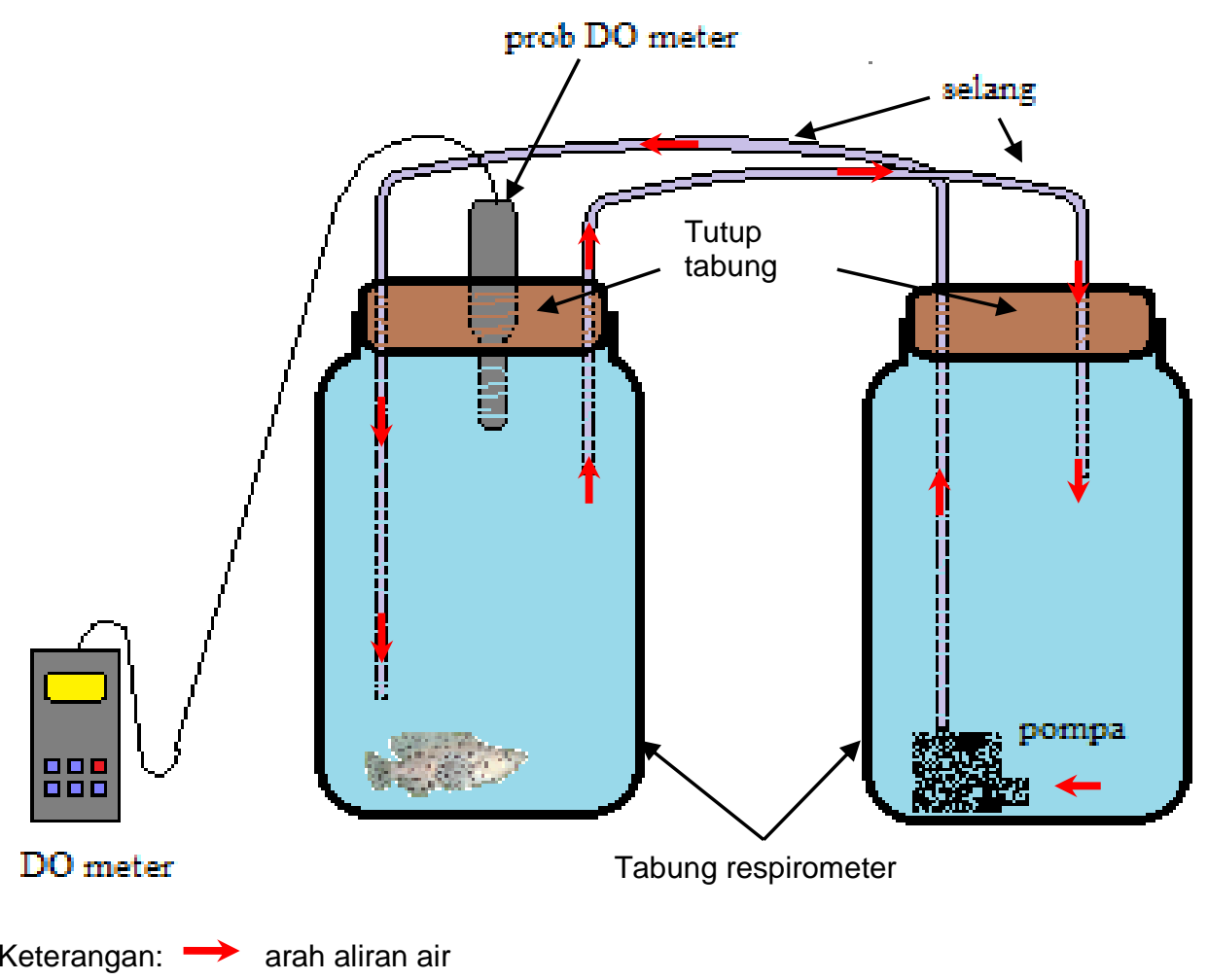

Gambar 1 Respirometer (closed system).

\section{Analisis data}

Data yang diperoleh untuk selanjutnya dianalisis dengan menggunakan persamaan Schreck dan Moyle (1990), guna memperoleh nilai laju konsumsi oksigen ikan. Persamaan yang digunakan adalah:

$$
K O=\frac{\left(D O_{0}-D O_{1}\right) \times V}{T}
$$

Keterangan:

$\mathrm{KO}=$ kecepatan konsumsi $\mathrm{O}_{2}$ ( $\mathrm{mg} \mathrm{O}_{2} /$ menit)

$\mathrm{DO}_{0}=$ oksigen terlarut saat awal pengukuran (mg/ltr)

$\mathrm{DO}_{1}=$ oksigen terlarut saat akhir pengukuran (mg/ltr)

$\mathrm{V}=$ = volume air dalam tabung respirometer

$\mathrm{T} \quad=$ waktu pengukuran (menit).

\section{HASIL DAN PEMBAHASAN}

Pada setiap periode waktu pengukuran konsumsi oksigen benih ikan kerapu, yaitu selama 2 jam, tidak terjadi perubahan suhu ruangan. Suhu ruangan pada setiap periode pengukuran konsumsi oksigen benih ikan kerapu adalah sebesar $27^{\circ} \mathrm{C}$.

\section{Suhu air laut selama pengukuran}

Grafik hasil pengukuran suhu air dalam tabung respirometer selama 2 jam pengamat- an, masing-masing pada kondisi $I_{s}$ dan $I_{k}$ disajikan pada gambar 2 Suhu yang ditunjukkan merupakan hasil rata-rata dari tiga kali pengukuran. Grafik tersebut memperlihat bahwa suhu ruang selama pengamatan tidak mengalami perubahan, sehingga dipastikan bahwa perubahan suhu air laut tidak dipengaruhi oleh faktor luar. Terlihat pula bahwa hasil pengukuran suhu air laut selama 2 jam pengamatan, baik pada kondisi $I_{i}$ dan $I_{k}$, mengalami peningkatan. Pada Gambar 2 juga terlihat bahwa pada kondisi kosong pun tetap terjadi perubahan suhu air laut selama 2 jam pengamatan. Perubahan berkisar antara $0,6-0,7^{\circ} \mathrm{C}$. Dugaan terjadinya perubahan suhu air laut pada kondisi kosong disebabkan adanya mesin pompa yang ditempatkan di salah satu tabung respirometer. Selama bekerja, mesin pompa menghasilkan panas yang selanjutnya mempengaruhi suhu air di sekitarnya.

Pada pengukuran suhu air di dalam tabung respirometer dimana tidak terdapat mesin pompa yang diaktifkan selama 2 jam pengukuran, diketahui bahwa suhu air di dalam tabung respirometer tersebut tetap baik di awal pengukuran tetap maupun setelah 2 jam pengamatan. Berdasarkan hasil tersebut dapat dipastikan bahwa perubahan suhu pada kondisi $I_{i}$ dan $\mathrm{I}_{\mathrm{k}} \mathrm{ti}-$ dak sepenuhnya diakibatkan oleh adanya aktivitas ikan di dalamnya, akan tetapi juga karena adanya mesin pompa yang saat bekerja menghasilkan panas. 


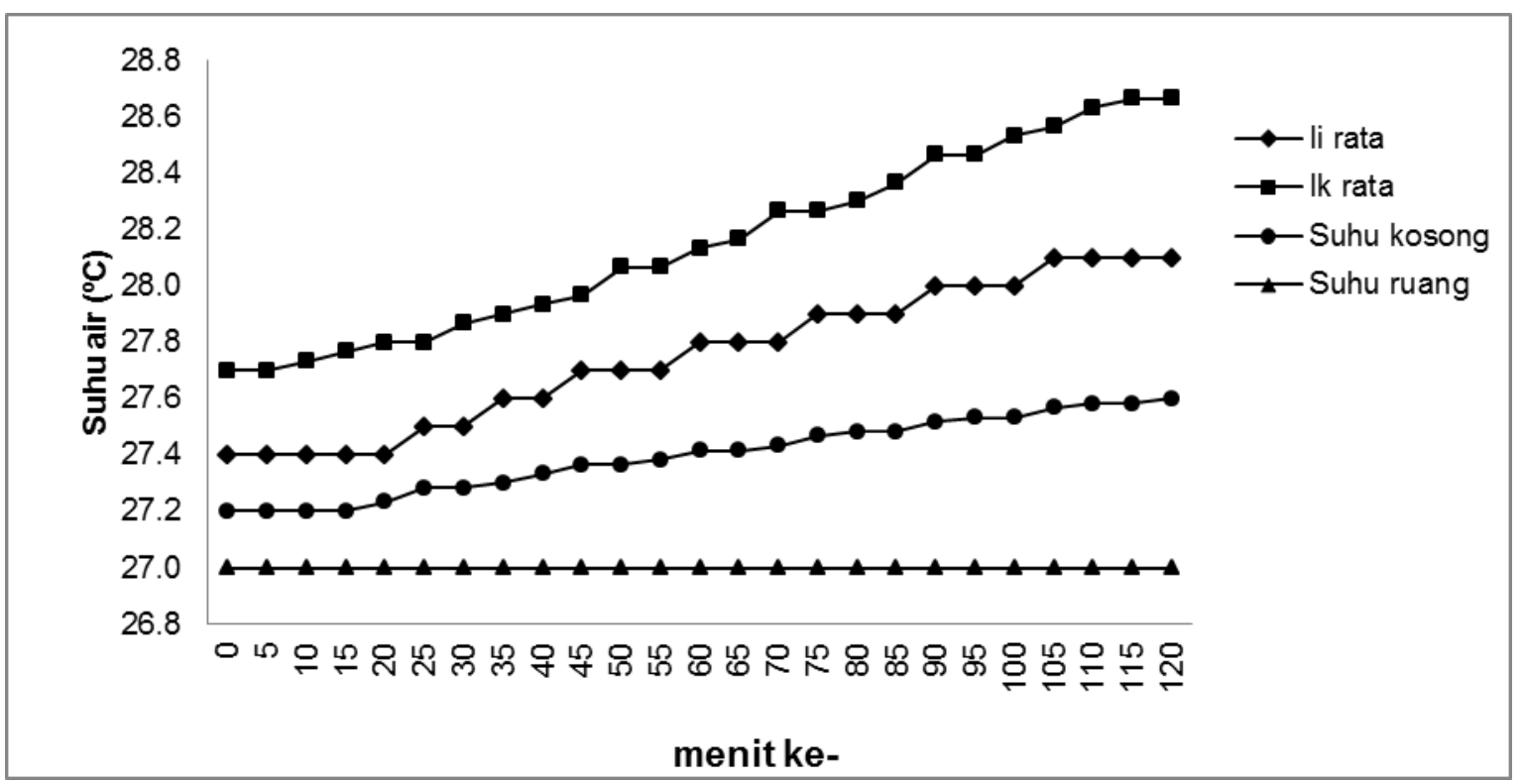

Gambar 2 Perubahan suhu air laut dan ruang selama 120 menit pengamatan pada kondisi $I_{s}$.

Dengan perhitungan sederhana, suhu air laut pada kondisi $l_{i}$ dan $l_{k}$ dikurangi dengan suhu air laut pada kondisi kosong, maka hasil pengurangan tersebut adalah merupakan suhu air laut yang disebabkan oleh aktivitas ikan. Dengan demikian, perubahan suhu air laut selama 2 jam pengamatan yang disebabkan oleh aktivitas ikan pada kondisi $l_{i}$ berkisar antara $0,1-0,3 \stackrel{\circ}{\circ}$. Adapun perubahan suhu air laut selama 2 jam pengamatan yang disebabkan oleh aktivitas ikan pada kondisi $I_{k}$ adalah berkisar antara $0,2-0,4 \stackrel{\circ}{\circ}$. Secara sederhana, dapat pula dihitung besarnya kontribusi tiap benih ikan terhadap perubahan suhu air pada kondisi pengukuran $I_{k}$, yaitu sebesar $0,07-0,13{ }^{\circ} \mathrm{C}$ per ikan selama 120 menit (2 jam). Dengan demikian terlihat bahwa kontribusi perubahan suhu air yang disebabkan oleh individu ikan yang berada tidak sendiri di dalam tabung respirometer ( $\mathrm{k}$ ) lebih kecil dibandingkan dengan kontribusi perubahan suhu air yang disebabkan oleh individu ikan yang berada sendiri di dalam tabung respirometer $\left(I_{s}\right)$.

Inoue et al. (2008) dan Chandroo et al. (2004) dalam penelitiannya menunjukkan bahwa terjadi peningkatan aktivitas ikan pada saat ikan mengalami stres. Stres dapat mengakibatkan meningkatnya produksi amoniak dan peningkatan suhu tubuh pada ikan. Grøttum and Sigholt (1998) menyebutkan bahwa metabolisme individu ikan dalam tabung respirometer lebih tinggi dibandingkan dengan di kolam budi daya. Tingkat stres yang tinggi dalam tabung respirometer diduga sebagai penyebab meningkatnya metabolisme dalam tubuh ikan. Kondisi ini disebabkan keterbatasan ruang gerak ikan di dalam tabung respirometer yang berbeda dengan kondisi normal keberadaan ikan di bak penampungan, keramba apung atau alamnya. Budi daya pembenihan ikan kerapu bebek biasanya dilakukan dalam keramba jaring apung atau bak penampungan. Benih-benih ikan tersebut ditempatkan bersama ratusan hingga ribuan benih ikan kerapu lainnya dalam satu unit penampungan. Kondisi benih ikan yang dimasukkan ke dalam tabung respirometer yang memiliki volume terbatas diduga menjadi penyebab meningkatnya metabolisme ikan akibat stres sehingga pada akhirnya menyebabkan peningkatan suhu air selama pengukuran. Walaupun demikian ketidaksendirian benih ikan di dalam tabung respirometer, diduga menjadi penyebab rendahnya tingkat stres ikan yang terjadi. Lebih rendahnya tingkat stres yang muncul, mengakibatkan peningkatan metabolisme dan suhu tubuh benih ikan tidak terlalu besar.

\section{Konsentrasi Oksigen Terlarut}

Individu benih ikan yang dimasukkan ke dalam tabung respirometer pada setiap pengukuran dan kondisi pengukuran tidak sama, tetapi semua benih ikan tersebut memiliki ukuran panjang total antara 5-7 cm. Penggunaan benih ikan yang berbeda pada setiap pengukuran dan kondisi pengukuran bertujuan untuk menghindari pengaruh faktor kebiasaan ikan di dalam tabung respirometer yang mungkin dapat terjadi. Ukuran panjang dan berat tiap benih ikan kerapu bebek yang digunakan disajikan pada Tabel 1.

Grafik nilai rata-rata konsentrasi oksigen terlarut pada kondisi $I_{i}$ dan $I_{k}$ serta kondisi kosong disajikan pada Gambar 3. Benih ikan kerapu bebek yang berukuran panjang antara 5 $\mathrm{cm}$ sampai dengan $7 \mathrm{~cm}$ memiliki kisaran berat 


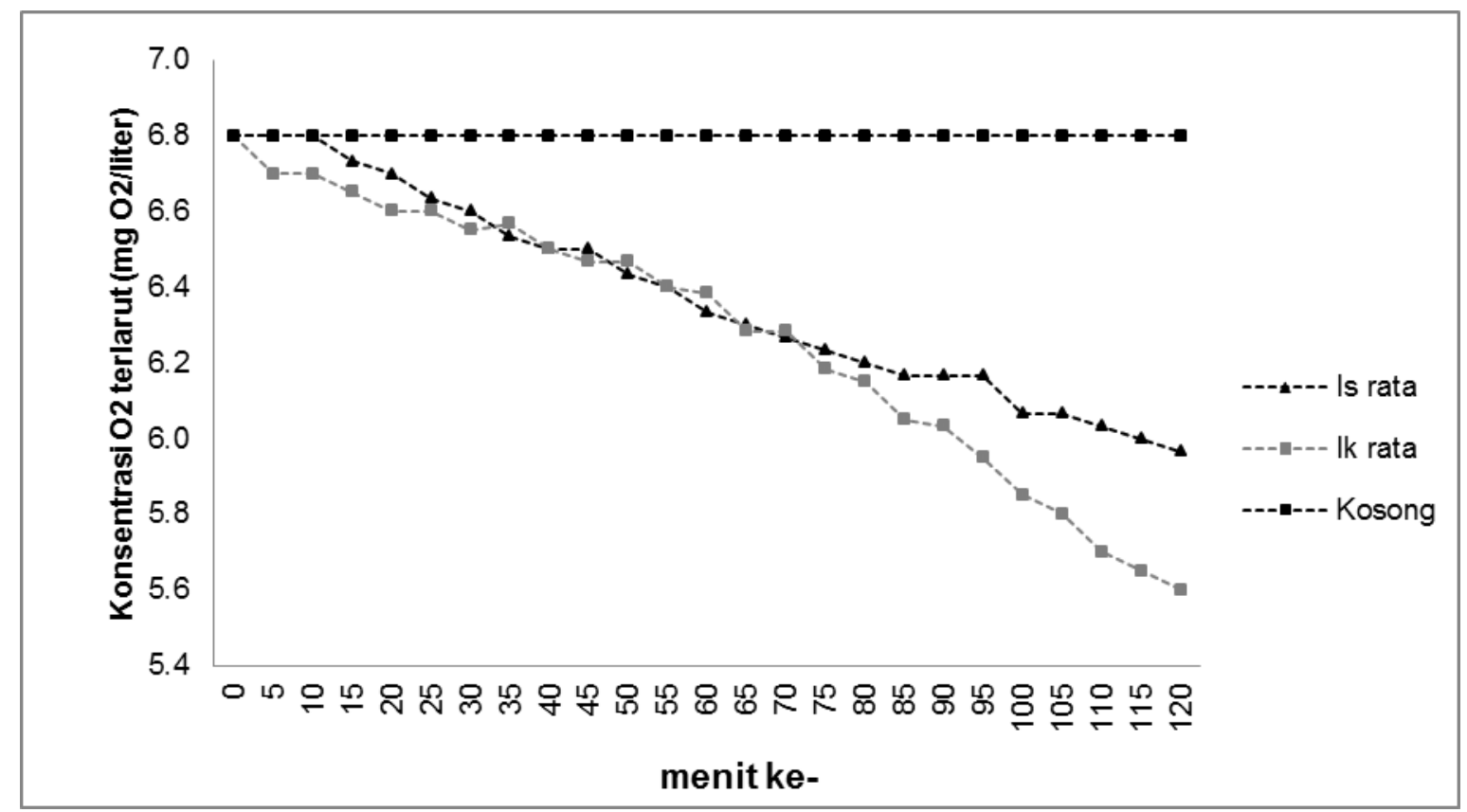

Gambar 3 Rata-rata perubahan konsentrasi oksigen terlarut selama 120 menit (2 jam) pada kondisi $l_{\mathrm{i}}$, lk dan kosong.

tubuh antara 3,35 gram hingga 3,86 gram per ikan (Tabel 1). Berdasarkan hasil pengukuran terhadap tinggi badan ikan yang diukur dari bagian perut paling bawah hingga bagian punggung paling atas berkisar antara 2,5 sampai dengan $2,8 \mathrm{~cm}$. Dengan demikian dapat dikatakan bahwa ukuran benih ikan kerapu yang digunakan relatif sama besar.

Gambar 3 menampilkan grafik perubahan nilai konsentrasi oksigen terlarut secara rata-rata dari tiga kondisi pengukuran, yaitu kondisi kosong ${ }_{r a t a}$, $l_{i}$ rata dan $l_{k}$ rata. Terlihat bahwa pada pengukuran kondisi kosong tidak terjadi pengurangan konsentrasi oksigen terlarut selama 2 jam pengamatan. Hal ini menunjukkan bahwa tidak terdapat penggunaan oksigen selama 2 jam pengamatan pada kondisi kosong. Adapun grafik perubahan konsentrasi oksigen terlarut pada pengukuran kondisi $l_{i}$ dan $I_{k}$, keduanya mengalami pengurangan. Jika grafik $I_{s}$ rata dan $\mathrm{I}_{\mathrm{k} \text { rata }}$ saling dibandingkan, maka terlihat bahwa mulai menit ke-0 hingga menit ke-70 pengamatan, kedua grafik cenderung mengalami penurunan yang relatif sama. Barulah pada menit ke-70 hingga ke-120, terjadi perubahan penurunan konsentrasi oksigen terlarut yang cukup signifikan di antara keduanya.

Gambar 3 memperlihatkan bahwa pada hasil pengukuran tanpa ikan (kondisi kosong) dan dengan ikan (kondisi $l_{i}$ dan $I_{k}$ ) terjadi penurunan konsentrasi oksigen terlarut di dalam tabung respirometer. Selain itu pada grafik hasil pengukuran konsentrasi oksigen terlarut pada dua kondisi yaitu kondisi $l_{i}$ dan $I_{k}$, terlihat bahwa kedua grafik tersebut pada 60 menit pertama relatif memiliki kecenderungan penurunan nilai konsentrasi oksigen terlarut yang sama, setelah itu terjadi perubahan nilai konsentrasi oksigen terlarut yang cukup signifikan antara kedua kondisi pengukuran tersebut hingga akhir pengukuran.

Sebagaimana telah dijabarkan sebelumnya, pengkondisian ikan yang berbeda dengan kondisi lingkungan yang selama ini ditempatinya, dapat menimbulkan stres pada ikan. Ikan yang stres akan mengalami peningkatan metabolisme di dalam tubuh yang ditandai de-ngan meningkatnya produksi amoniak dan suhu tubuh. Berdasarkan hasil pengukuran suhu air laut pada pembahasan sebelumnya, terlihat bahwa peningkatan suhu air laut yang disebabkan oleh satu ekor benih ikan kerapu bebek pada kondisi li lebih besar dibandingkan dengan satu ekor benih ikan kerapu bebek pada kondisi Ik. Lebih besarnya perubahan konsentrasi oksigen terlarut dan suhu air di dalam tabung respirometer yang disebabkan oleh individu benih ikan yang sendirian di dalam tabung respirometer (kondisi li) menunjukkan kecenderungan untuk menduga bahwa ikan tersebut mengalami tingkat stres yang lebih tinggi dibandingkan individu benih ikan yang tidak sendirian di dalam tabung respirometer (kondisi $l_{k}$ ).

\section{Konsumsi Oksigen}

Penentuan konsumsi oksigen ikan dilakukan dengan mengukur konsentrasi oksigen di awal dan diakhir pengukuran dengan memperhitungkan volume air dan waktu pengukuran sebagaimana persamaan yang dikemukakan 
Tabel 1 Ukuran benih ikan dan nilai konsumsi oksigen.

\begin{tabular}{|c|c|c|c|c|}
\hline \multirow{2}{*}{ Kondisi } & \multirow{2}{*}{ Pengukuran } & \multicolumn{2}{|c|}{$\begin{array}{c}\text { Ukuran Benih Ikan Kerapu } \\
\text { Bebek }\end{array}$} & \multirow{2}{*}{$\begin{array}{l}\text { Konsumsi Oksigen/ekol } \\
\text { (mg O } 2 / \text { jam/ekor) }\end{array}$} \\
\hline & & $\begin{array}{l}\text { Panjang } \\
\text { (cm) }\end{array}$ & Berat (gram) & \\
\hline \multirow{3}{*}{$I_{s}$} & ke-1 & 6,5 & 3,47 & 1,836 \\
\hline & ke-2 & 6,6 & 3,55 & 1,632 \\
\hline & ke-3 & 6,8 & 3,58 & 1,632 \\
\hline \multicolumn{2}{|c|}{ Nilai tengah: } & & & 1,734 \\
\hline \multirow[t]{9}{*}{$\mathrm{I}_{\mathrm{k}}$} & $\mathrm{ke}-1$ & 6,8 & 3,40 & \\
\hline & & 6,9 & 3,62 & 0,884 \\
\hline & & 6,1 & 3,35 & \\
\hline & ke-2 & 6,8 & 3,55 & \\
\hline & & 6,9 & 3,86 & 0,816 \\
\hline & & 6,7 & 3,43 & \\
\hline & ke-3 & 6,7 & 3,63 & \\
\hline & & 6,8 & 3,70 & 0,748 \\
\hline & & 6,7 & 3,51 & \\
\hline \multicolumn{2}{|c|}{ Nilai tengah: } & & & 0,816 \\
\hline
\end{tabular}

oleh Schreck dan Moyle (1990) (persamaan 1). Sebelum pengukuran konsumsi oksigen ikan, terlebih dahulu dilakukan pengukuran dalam kondisi kosong, yaitu pengukuran dalam tabung respirometer tanpa ikan di dalamnya, dengan tujuan untuk memastikan bahwa air laut yang berada di dalam tabung respirometer tidak berisi jasad renik atau jikapun ada, keberadaannya tidak mempengaruhi konsentrasi oksigen terlarut di dalam tabung respirometer.

Berdasarkan hasil pengukuran saat kondisi kosong, konsentrasi oksigen terlarut di awal dan di akhir pengukuran tidak berubah (Gambar 3). Kondisi ini menunjukkan bahwa air laut di dalam tabung respirometer tidak mengandung jasad renik atau jikapun ada, keberadaannya tidak mempengaruhi konsentrasi oksigen terlarut di dalam tabung tersebut. Pada Tabel 1 juga disajikan nilai konsumsi oksigen yang diperoleh dengan menggunakan persamaan 1 .

Tabel 1 menunjukkan bahwa nilai konsumsi oksigen tiap individu pada pengukuran kondisi $\mathrm{l}_{i}$ berkisar antara 1,632-1,836 mg/jam dengan nilai tengah sebesar $1,734 \mathrm{mg} / \mathrm{jam}$. Adapun nilai konsumsi oksigen rata-rata tiap individu pada pengukuran kondisi $\mathrm{l}_{\mathrm{k}}$ berkisar antara $0,748-0,884 \mathrm{mg} / \mathrm{jam}$ dengan nilai tengah sebesar $0,816 \mathrm{mg} / \mathrm{jam}$. Jika mengacu pada nilai tengah konsumsi oksigen pada kedua kondisi pengukuran, maka nilai konsumsi oksigen benih ikan kerapu bebek (Cromileptes altivelis) ukuran panjang antara 5-7 $\mathrm{cm}$ berkisar antara 0,816-1,734 mg/jam per ekor.

Berdasarkan pemaparan di atas terlihat bahwa nilai konsumsi oksigen individu ikan dalam kondisi $\mathrm{I}_{\mathrm{k}}$ lebih kecil jika dibandingkan de- ngan nilai konsumsi oksigen individu ikan dalam kondisi $I_{i}$. Jika dikaitkan dengan pemaparan sebelumnya tentang perubahan suhu air, lebih kecilnya nilai konsumsi oksigen satu ekor ikan yang tidak dalam kondisi sendiri mungkin saja terjadi. Diduga ikan dalam kondisi sendiri di dalam tabung respirometer (kondisi li) lebih stres dibandingkan dengan ikan yang tidak sendiri di dalam tabung respirometer (kondisi $I_{k}$ ). Sehingga diduga metabolisme ikan yang sendiri lebih tinggi dibandingkan dengan metabolisme ikan yang tidak sendiri.

\section{Amoniak tak terionisasi $\left(\mathrm{NH}_{3}\right.$ un-ionized)}

Gowen and Bradbury (1987) dalam Leung et al. (1999), menyatakan bahwa lebih dari $50 \%$ nitrogen yang masuk ke dalam sistem budidaya perikanan laut adalah merupakan hasil pembuangan ikan. Ikan mengeluarkan nitrogen dalam bentuk ammonia, urea, amines dan amino acids.

Boyd (1982) menyatakan bahwa total ammonia nitrogen $\left(\mathrm{NH}_{3}-\mathrm{N}\right)$ adalah merupakan penjumlahan dari ion ammonium $\left(\mathrm{NH}_{4}{ }^{+}\right)$dan $\mathrm{NH}_{3}$ un-ionized. Ion ammonium tidak bersifat racun bagi ikan. Lain halnya amoniak unionized bersifat racun bagi ikan. Amoniak tersebut akan lebih bersifat racun lagi apabila terdapat pada perairan dengan konsentrasi oksigen terlarut yang rendah. The European Inland Fisheries Advisory Commission (1973) dalam Boyd (1982) menyatakan bahwa konsentrasi amoniak yang membahayakan dalam waktu singkat adalah jika mengandung 0,6 sampai dengan 2,0 mg/liter dari $\mathrm{NH}_{3}-\mathrm{N}$ untuk hampir semua jenis ikan. 
Berdasarkan hasil uji kandungan amoniak un-ionized selama pengukuran berlangsung (2 jam) pada setiap kondisi pengukuran, $\mathrm{NH}_{3}$ un-ionized yang dihasilkan oleh individu ikan kondisi $\mathrm{l}_{\mathrm{i}}$ rata-rata mencapai $0,021 \mathrm{mg} / \mathrm{liter}$. Adapun kandungan $\mathrm{NH}_{3}$ un-ionized yang dihasilkan oleh kelompok ikan kondisi $\mathrm{I}_{\mathrm{k}}$ rata-rata mencapai 0,017 mg/liter. Diperkirakan produksi amoniak un-ionized untuk 1 ekor ikan pada kondisi $l_{k}$ sebesar 0,006 mg/liter. Sebagaimana yang telah disebutkan sebelumnya oleh Inoue et al. (2008) dan Chandroo et al. (2004), stres ikan mengakibatkan peningkatan metabolisme atau aktivitas ikan yang ditandai salah satunya adalah dengan meningkatnya produksi amoniak. Tingkat stres yang lebih rendah pada ikan yang tidak sendiri dibandingkan dengan ikan yang sendiri menjadi penyebab produksi amoniak rata-rata oleh 1 ekor ikan pada kondisi tidak sendiri (kondisi $\mathrm{I}_{\mathrm{k}}$ ) menjadi lebih kecil dibandingkan dengan produksi amoniak ikan yang sendiri (kondisi $\mathrm{l}_{\mathrm{i}}$ ).

Pada kondisi tertutup sebagaimana yang terjadi pada tabung respirometer selama pengukuran konsentrasi oksigen terlarut dilakukan, diduga akan selalu terjadi akumulasi pertambahan suhu air dan amoniak yang pada akhirnya akan menambah tingkat stres ikan. Secara sederhana dapat dideskripsikan proses terjadinya peningkatan level stres pada ikan yang terdapat di dalam tabung respirometer selama pengukuran. Panas yang dihasilkan oleh mesin yang bekerja, akan meningkatkan suhu air di dalam tabung respirometer. Suhu air menurut FishVet.Inc (2000) adalah salah satu faktor fisika lingkungan yang dapat menyebabkan ikan stres. Perubahan suhu lingkungan tersebut segera dirasakan oleh ikan yang ada di dalamnya. Tubuh ikan mulai bereaksi untuk beradaptasi dengan adanya peningkatan suhu lingkungan, yaitu berupa peningkatan metabolisme dalam tubuh ikan. Peningkatan metabolisme ikan akan mengakibatkan semakin bertambahnya keluaran amoniak dari tubuh ikan, dimana amoniak merupakan salah satu faktor kimia lingkungan yang dapat mengakibatkan ikan stres. Peningkatan metabolisme ikan akan diikuti oleh peningkatan konsumsi oksigen terlarut oleh ikan. Selama pengukuran dilakukan, tidak terjadi penambahan konsentrasi oksigen terlarut dalam air yang terdapat dalam tabung respirometer. Peningkatan konsumsi oksigen oleh ikan, mengakibatkan ketersediaan oksigen terlarut di lingkungan semakin berkurang. Pengurangan konsentrasi oksigen terlarut di lingkungan, merupakan salah satu faktor fisik lingkungan selain suhu air yang dapat mengakibatkan ikan stres. Pertambahan suhu air dan amoniak serta pengurangan konsentrasi oksigen terlarut di lingkungan yang terjadi secara terus menerus di duga sebagai penyebab meningkatnya level stres ikan di dalam tabung respirometer. Terlebih jika kandungan amoniak di lingkungan sangat tinggi, maka akan semakin cepat terjadinya peningkatan level stres pada ikan, dan mungkin saja akan mempercepat kematian ikan.

\section{KESIMPULAN}

Berdasarkan hasil penelitian, dapat disimpulkan bahwa: konsumsi oksigen benih ikan kerapu bebek (Cromileptes altivelis) ukuran panjang 5-7 cm (total length) berkisar antara 0,816-1,734 mg/jam per ekor atau sebesar 0,231-0,492 mg/gr berat/jam. Peningkatan konsentrasi $\mathrm{NH}_{3}$ un-ionized pada air laut setelah pengukuran kondisi sendiri lebih besar jika dibandingkan dengan setelah pengukuran kondisi tidak sendiri atau kelompok, kondisi ini diduga terjadi karena kondisi ikan yang lebih stres pada kondisi sendiri.

\section{DAFTAR PUSTAKA}

Bailey D.M., A.J. Jamieson P.M., Bagley M. A., Collins \& I.G. Priede. 2002. Measurement of in Situ Oxygen Consumption of Deep-sea Fish Using an Autonomous Lander Vehicle. Vol. 49: 1519-1529.

Berg A., A. Danielsberg and A. Seland. 1993. Oxygen Demand for Postmolt Atlantic Salmon (Salmo salar L). Fish Farming Technology. Rotterdam. P: 297-300.

Boyd C.E. 1982. Water Quality Management for Pond Fish Culture. Elsevier Scientific Publishing Company. Amsterdam, Oxford, New York. 318 hal.

Chandroo K.P., L.J.H. Duncan \& R.D. Moccia. 2004. Can fish suffer?: pers-pectives on sentience, pain, fear and stress. Applied Animal Behaviour Sci-ence. Vol. 86 (2004): $225-250$.

FishVet.Inc. (2000). Fish Stress and Disease Overview. www.fishvet.com. Diunduh tanggal 2 Oktober 2009.

Fivelstad S. and M.J. Smith. 1991. The Oxygen Consumption Rate of Atlantic Salmon (Salar salmo $L$ ) reared in a Single Pass Landbased Seawater System. Aquacultural Engineering. Vol. 10: 227-235

Grøttum J.A. and T. Sigholt. 1998. A model for Oxygen Consumption of Atlantic Salmon (Salmo salar) Based on Measurements of individual fish in a Tunnel Respirome- 
ter. Aquacultural Engineering. Vol. 17: 241-251.

Inoue L.A.K.A., G. Moraes, G.K. Iwama \& L.O. B. Afonso. 2008. Physiological stress responses in the warm-water fish matrinxa (Brycon amazonicus) subjected to a sudden cold shock. Acta Amazonica, Vol. 38(3) 2008: 603-610.

Leung K.M.Y., J.C.W. Chu \& R.S.S. Wu. 1999. Effects of Body Weight, Water Temperature and Ration Size (Epinephelus areolatus) and Mangrove snapper
(Lutjanus argentimaculatus). Aquaculture. Vol. 170: 215-227.

Schreck C.B. and P.B. Moyle. 1990. Methods for Fish Biology. American Fisheries Society. Bethesda, Maryland, USA. 684 hal.

Zimmermann C. and A. Kunzmann. 2001. Baseline Respiration and Spontaneous Activity of Sluggish Marine Tropical Fish of The Family Scorpaenidae. Marine Ecology Progress Series. Vol. 219: 229239. 